\title{
DETERMINANTS OF ENTREPRENEURIAL BUSINESS RELATIONSHIP SUCCESS
}

\author{
Muhammad Khan Rahatullah* \\ Effat University Jeddah \\ Robert Raeside \\ Edinburgh Napier University
}

\begin{abstract}
The business development literature illustrates the importance of relationships on achieving targets and ensuring the sustainability of enterprises. In this paper the sphere of franchising which is essentially an entrepreneurial business is used to link measures of business relationships in the domains of trust, credibility, commitment, integrity, confidence and trust to the success of the business. It is found that irrespective of size and age of the franchise and business sector of operation that these relationships are important determinants of success. Although they do not act directly to enhance the prospect of success it is via their interactions that success arises.
\end{abstract}

Keywords: Entrepreneurial Business; Business-to-Business Relationships; Franchising; Trust and Commitment.

\section{INTRODUCTION}

In business as in many spheres of life relationships built on trust and mutual commitment are important. These relationships require nurturing and fostering and it is proposed that the secure development of these will allow businesses to achieve success and competitive advantage (See Barney 1991, Contractor and Lorange 1988, Frigo 2003 and Ulaga and Eggert 2006). In franchising which is an entrepreneurial business where two entrepreneurs franchisors and franchisees enter into relationships which are explicit and as such the study of franchising relationships make a good platform for the study of business to business relationships (Powell 1987 and 1990, Shane 1996a and Swenson et al 1990). Franchising is important to the economy, as in Great Britain some 33000 people are employed in this activity and the contribution to GNP is in excess of $£ 10 b$. (BFA/NATWEST survey 2005). However, Shane and Spell (2002) draw attention to the fact that more than 33 per cent of franchises cease to exist within the first four years and more than 75 per cent stop operations before their twelfth anniversary. There is a need to study franchising relationships in order to ascertain the attributes of good practice, especially in the vulnerable stages of firm ages like 1-5 years old and 6-8 years old to understand the strategies and process in these times.

Corresponding author: Dr. Muhammad Rahatullah Khan, Entrepreneurship department, Effat University, Jeddah 21478, P.O. Box. 3689 Saudi Arabia. Phone No.: ++966548098960. Email: mkhan@efffatuniversity.edu.sa 
Ring and van de Ven (1994) forward a framework for the study and development of inter organizational relationships. This is based on the assumptions that partners have the will and are committed to create and maintain long-term relationships. Ring and van de Ven argue that relationships are maintained and evolve through repeated negotiation, commitment and in their execution. Contracts either formal legal or of a psychological nature are the basis on which commitment is displayed and the fulfillment of these contracts form the basis of performance assessment. To enhance performance interactions between partners are important as shown by Cunningham and Homse (1986) and imply, according to Holm et al (1999) a loss of individual unit identity.

Hadjikhani and Thilenius (2005) consider that the organizational relationships are both a vertical (from supplier to customer) and a horizontal dyadic relationship between business units of a similar level. In order to develop these relationships mutually agreed strategies are required as argued by Huxham and Macdonald (1992), Barney (1996) and Perry et al (2002). Child and Faulkner (1998) and Miyamoto and Rexha (2004) indicate that cooperative strategies are required for success and create mutual trust and commitment will be an outcome. Trust and commitment lead to consensus (Baucus et al 1996) and Bourgeois 1980 and Dess and Davis 1984 associated competitive advantage with consensus. According to Coote et al. (2003) this trust will mediate the effects of communication and inter-party interaction on commitment.

It is well known from the work of scholars such as Costa (2003) that good, efficient and equitable cooperation leads to increased likelihood of improved business results. Trust is the basis for this cooperation (see Atuahene-Gima 1996) and trust in the cooperative network environment helps to reduce uncertainty, enhances flexibility and increases capacity through access to resources and information exchange, (see Arthur 1996). Dant and Nasr (1998) and Gundlach et al. (1995) state that cooperation helps in the maximization of collective benefit across the network and this will help the management of information in the network relationships, minimize the divergence of goals, uncertainty and the behavioral actions of partners which can damage the relationship and so conflicts amongst partners is reduced. This work has been further deliberated upon and developed by Huxham (1992) and Lawler and Yoon 1996).

Trust in the relationships throughout the franchise network is defined by Ndubisi and Wah (2005) as "one party's confidence in another that he will not be harmed; or one party will not act in a way that is not beneficial to the other". Moorman et al. (1993) state that "trust is the willingness to rely on another exchange partner in whom one has confidence". According to Costa (2003) "trust plays a vital role in relationship development, sustenance and growth, and is a vital ingredient for the overall business development". The development of this leads to quality and adds value in the relationship. The importance of trust in business relationships has been studied by a number of researchers. Anderson and Narus (1990), Inkpen and Birkenshaw (1994) and Hakansson and Snehota (1995) illustrate the importance of trust to the network and in creating and maintaining interactions in that network.

Confidence is considered to be the foundation of trust building and to the strength of the relationship by researchers such as Geyskens et al. (1999) and Sarkar et al (1997). Ganesan (1994) and Nicholson et al. (2001) consider that confidence in business relationships is 
developed when one party has the emotions of integrity, benevolence and credibility towards the other. When partners aspire to maintain their relationship with each other in a dyadic relationship commitment is considered to be present (de Ruyter et al. 2001). On the other hand the Commitment is also related to trust and Ganesan (1994) and Tellefsen (2002) illustrate the importance to commitment in the buildup and persistence of the relationship and its role in securing consensus of the partners towards joint goals.

Other facets influencing trust are credibility, integrity and benevolence. Credibility according to Ganesan (1994) is the ability and expertise of the partner to undertake the purpose of the relationship. Mayer et al. (1995) indicates that credibility is the expectation that a partner can perform to a certain standard, and possess ample competency and characteristics to perform. Integrity is evident when partners comply with ethical standards and keep promises, (see Nicholson et al. 2001). The benevolence component of trust refers, according to Ganesan (1994) to the fact that a benevolent partner will act, adopt and adapt to new conditions as demanded and a partner has willingness to perform more than expected. If a situation of conflicting goals arises, between partners benevolence implies that one partner will place their partners' interests above their own, (see Sako 2000). Coletti et al. (2005) shows that as benevolence increases the partners develop moral obligations and responsibilities to place concern for the interests of others above their own.

According to Ring and van de Ven (1992) the existence of trust generates confidence and the partners will be willing to work together on a reciprocal basis and share recourses and information. Mayer et al. (1995) and Sako (2000) consider that three implications arise from this discussion on trust. Firstly trust is multidimensional in that it contains both attitudes and actions, secondly trust requires choice and thirdly the lack of or the deterioration of trust will result in withdrawal of activities and failures arise.

\section{GAPS AND QUESTIONS}

The above discussion shows that the trust and its associated facets of credibility, integrity, benevolence, that lead to confidence and commitment in order to achieve consensus to assure cooperative strategy are important to business relationships. The partner actions determine and develop these components of trust. These also appear more strategically significant in franchise relationships where there is symbiotic reliance on partners.

However, the aforementioned literature shows that no information is available to identify the actions partners should strategically take in order to earn and manifest their trust and commitment to each other. Hence there is a need to understand what actions will develop the franchisors confidence, credibility, integrity and benevolence and how these qualities of trust can be communicated through the franchise network. Colette et al. (2005) also draws attention to the dearth of information on the effects of control systems on trust and cooperation in collaborative relationships.

Accordingly in order to advise as to how best to manage franchising relationships there is a need to investigate control systems as well. 


\section{METHODS}

To facilitate ascertaining how domains of the relationships of trust, confidence, credibility, integrity and benevolence and commitment might be related to the performance of the franchise a questionnaire based survey of franchisors in Great Britain was conducted.

According to Kidder and Judd (1986) in any scientific research there are three types of validity needed i.e. construct, internal and external. These are considered important in quantitative research. While these validity criteria are established for evaluating experimental research but are not fully achievable in 'real world' settings. However, they act as a useful benchmark to measure strengths and weaknesses of research. In the subject study, one of the statistical reliability of the factors was achieved by Cronbach alpha measure, which is an index of reliability for a set of items to show the extent to which items measure the same characteristics. If the resultant value is, more than .500 results are considered reliable.

Salthouse et al. (2004) suggest that having high construct validity means all the constructs that research intended to study have been successfully represented by the specific variables. This was assessed in pilot study and adjustments were made accordingly in the survey instrument.

Kidder and Judd (1986) and Foster et. al. (2006) argue that external validity is concerned with the generalize ability of the research results to other similar settings of interest. This was achieved through in-depth interviews of franchisors, academics and practitioners who validated the findings.

From the survey results a model of the relationship of these domains of success is developed. Similarly, it is also investigated that how these domains vary with franchise size and age are also investigated. The investigations are mainly carried out using SPSS and AMOS. The factors are initially developed for the factors of trust and its components and then the correlations, regression and path modeling is computed and constructed to ascertain the factors related to success

In the next section the data collection process is outlined and the responses summarized. Then in section three, factor analysis is used to construct derived variables to represent each of the facets associated with trust. These variables are then related to measures of success using regression methods and a path model of the whole system is presented. In the final section conclusions are made and a discussion is given. This analysis was conducted controlling for age, size and the sector of the franchise. The age and size groups developed are shown in table 1, and follow the categorization of Shane and Spell (2002).

\subsection{Sample and Data Collection}

The main method of data collection used was a detailed structured questionnaire. Questions were asked to elucidate on the different relationship domains as identified in the literature. This was developed from the literature; exploratory interviews of ten franchisors and piloting on another 7 franchisors. In UK at the time of survey there were 619 franchise companies as per 
Table 1: The age and size groups

\begin{tabular}{cc}
\hline Age & Size \\
\hline Nascent 1-5 years & Micro 1-15 franchisees \\
Young 6-8 years & Small 16-50 franchisees \\
Older 9-11 years & Medium 51-100 franchisees \\
Mature 12+ years & Large 100+ franchisees \\
\hline
\end{tabular}

list of franchisors held by the British Franchise Association at their website www.bfa.org; and from other web sources such as www.whichfranchise.com and www.ifa.org. Companies were telephoned in advance apprising them that the questionnaire was being sent in an attempt to ensure their inclusion in the survey and after a number of reminders 124 companies completed the questionnaire. This provided a response rate of $20.03 \%$. The nature of the respondents is summarized in Table II.

Table 2: The nature of the responding franchisors

\begin{tabular}{|c|c|c|c|c|c|c|c|c|c|}
\hline \multirow{2}{*}{ Business Sector } & \multicolumn{4}{|c|}{ Age } & \multicolumn{4}{|c|}{ Size } & \multirow{2}{*}{ Total } \\
\hline & Nascent & Young & Older & Mature & Micro & Small & Medium & Large & \\
\hline \multicolumn{10}{|l|}{ Specialized } \\
\hline Services & 8 & 5 & 4 & 14 & 7 & 13 & 6 & 5 & 39 \\
\hline \multicolumn{10}{|l|}{ Fast Food and } \\
\hline Restaurants & 1 & 2 & 2 & 3 & 2 & 2 & 2 & 2 & 8 \\
\hline \multicolumn{10}{|l|}{ Automobile } \\
\hline Services & 1 & 1 & 3 & 3 & 1 & 4 & 1 & 2 & 7 \\
\hline Property & 8 & 2 & 7 & 33 & 8 & 19 & 13 & 10 & 49 \\
\hline Specialized Retail & 2 & 1 & 3 & 7 & 1 & 4 & 2 & 6 & 9 \\
\hline \multicolumn{10}{|l|}{ Education \& } \\
\hline Training & 1 & 2 & 2 & 9 & 3 & 6 & 2 & 3 & 12 \\
\hline Total & 21 & 13 & 21 & 69 & 22 & 48 & 26 & 28 & 124 \\
\hline
\end{tabular}

Questions asked were designed to enquire about the demographic details of the franchise; it then considered success of the franchise in relation to which desired goals were achieved and direct questions of the various attributes of the different facets of trust and commitment. These were asked on an 11 point Likert scale to enable wider generalization and were of the form "the degree to which $\mathrm{X}$ attribute was important. The variables obtained from subsets of these questions were then combined to expose latent variables associated with each dimension of the facets of trust and commitment. This is the subject of the next section.

To measure success franchisors were asked to report their success, on an eleven point scale, in relation to ten motivations for franchising and the degree of importance of that motivation, (also on an eleven point scale). These motivations were: To grow business and increase market 
share, enter new markets, increase manufacturing capability, increase distribution capability, growth and stability of target market, Government incentive schemes, Capability to operate, To decrease costs, To overcome resource constraints, To recover otherwise unrecoverable costs.

A "success" score was computed using the calculation below:

$$
\sum_{i=1}^{n=8} S_{i} I_{i}
$$

Where $\mathrm{i}=1$ to 8 reason, $\mathrm{S}_{\mathrm{i}}=$ success of reason $\mathrm{I}$ and $\mathrm{I}_{\mathrm{i}}=$ importance of reason $\mathrm{i}$. This score was normally distributed with mean 51.3 and standard deviation 13.9.

\subsection{Derivation of facets of trust and commitment}

Six domains of relationships were derived from the literature; trust, confidence, credibility, integrity, benevolence and commitment. The questions pertaining to each domain were combined using factor analysis with Varimax rotation. These are displayed in Table 3 along with their factor loading and Cronbach's reliability coefficient which should be at least greater than 0.5. In regard to trust five factors explained almost 70 per cent of the original variance of questions considered to be associated with trust and Cronbach's Alpha showed an acceptable reliability coefficient of 0.687 . These factors have been labeled franchisee compliance, responsibility, performance and consensus. Three factors were derived from the questions listed in Table 3 which were considered to represent issues related to confidence, these factors have been labeled as strategic acceptance, expertise and acknowledgement, (Cronbach's alpha of this set of factors was 0.603 ).

Four factors were taken to represent credibility; these have been labeled operations, sincerity, honesty and acquiescence. Integrity is represented by three factors have been labeled as managerial, financial and respect. Two factors were derived to represent benevolence was labeled as recognition and participation. Three factors were then derived to represent commitment and are labeled as adherence, proactively and mutuality.

\section{DISCUSSION}

This section discusses the hybrid relationship to success determinants. The factors derived in the previous section are now related to self-reported measures of franchise success and are displayed in Table 3. The factors which correlated with success are Performance in the trust domain, Sincerity in the credibility domain, mutuality in the commitment domain, managerial in the integrity domain and participation in the benevolence domain. Elements from the confidence domain were not found to correlate with success. From Tables 4 and 5 it is evident that factors of different domains of the relationships are also correlated. 
Table 3: Factor analysis of relationship domains

\begin{tabular}{|c|c|c|c|c|c|}
\hline \multirow[b]{2}{*}{ Variables } & \multicolumn{5}{|c|}{ Factors and Loadings } \\
\hline & $\begin{array}{l}\text { Franchisee } \\
\text { compliance }\end{array}$ & Responsibility & Performance & Consensus & $\begin{array}{l}\text { Participating } \\
\text { and } \\
\text { Compromising }\end{array}$ \\
\hline \multicolumn{6}{|l|}{ Trust } \\
\hline $\begin{array}{l}\text { Franchisee ensuring adherence } \\
\text { to agreement }\end{array}$ & 0.773 & -0.014 & 0.145 & 0.213 & 0.345 \\
\hline $\begin{array}{l}\text { If franchisee do not misrepresent } \\
\text { financial data }\end{array}$ & 0.665 & 0.08 & 0.229 & 0.456 & 0.033 \\
\hline $\begin{array}{l}\text { Adherence to quality and } \\
\text { operational manual }\end{array}$ & 0.732 & 0.065 & 0.123 & 0.335 & 0.078 \\
\hline $\begin{array}{c}\text { Franchisee implementing changes } \\
\text { necessary to keep competitive }\end{array}$ & 0.775 & 0.011 & 0.111 & 0.012 & 0.116 \\
\hline On-time royalty payments & 0.789 & -0.035 & 0.145 & 0.034 & $0 . .317$ \\
\hline $\begin{array}{l}\text { If there is no risk of damaging } \\
\text { brand and reputation }\end{array}$ & 0.617 & -0.068 & 0.087 & 0.012 & 0.401 \\
\hline Franchisee should report on time & -0.106 & 0.008 & 0.489 & 0.645 & 0.216 \\
\hline $\begin{array}{l}\text { When franchisee actively } \\
\text { participates in service and or } \\
\text { product development }\end{array}$ & 0.257 & 0.089 & 0.123 & 0.525 & 0.525 \\
\hline $\begin{array}{l}\text { If franchisee does not avoid } \\
\text { responsibility }\end{array}$ & 0.123 & 0.828 & 0.178 & 0.047 & 0.201 \\
\hline $\begin{array}{l}\text { If franchisee has problem solving } \\
\text { approach }\end{array}$ & 0.23 & 0.833 & 0.177 & 0.146 & 0.198 \\
\hline $\begin{array}{l}\text { When franchisee manages his } \\
\text { business and cooperates for } \\
\text { business development }\end{array}$ & 0.323 & 0.365 & 0.683 & 0.441 & 0.032 \\
\hline $\begin{array}{l}\text { If franchisee meets his obligations } \\
\text { if franchisee shows increased }\end{array}$ & -0.169 & 0.35 & 0.786 & 0.124 & 0.112 \\
\hline sales every time & 0.506 & 0.172 & 0.618 & 0.414 & 0.345 \\
\hline Honoring of commitments & -0.143 & 0.045 & 0.024 & 0.451 & 0.321 \\
\hline $\begin{array}{l}\text { Consensus on common issues } \\
\text { and objectives }\end{array}$ & 0.079 & 0.078 & 0.219 & 0.848 & 0.848 \\
\hline $\begin{array}{l}\text { Cooperation to achieve the } \\
\text { agreed targets }\end{array}$ & 0.172 & 0.149 & 0.346 & 0.771 & 0.122 \\
\hline Variance & 27.36 & 21.11 & 16.64 & 11.77 & 8.61 \\
\hline
\end{tabular}


Table 3: Factor analysis of relationship domains (cont)

\section{Confidence}

Show of managerial and business expertise

Show of technical skills

Acceptance of franchisor efforts and assistance

Recognition that franchisor is the boss

Consistency

Clear communications

Self-sufficiency in unit management

Understanding and accepting franchisor strategy

Cooperation to achieve and implement the agreed targets and strategy

Respect for principles on which system is based

Respect for franchisors' achievement and guidance

Variance

\begin{tabular}{lll}
\hline Strategic acceptance & Expertise & Acknowledgement \\
\hline
\end{tabular}

$\begin{array}{lll}0.053 & 0.821 & 0.061 \\ -0.620 & 0.837 & -0.031 \\ -0.051 & 0.039 & 0.827 \\ & & \\ -0.076 & 0.060 & 0.500 \\ 0.596 & 0.084 & -0.304 \\ 0.675 & 0.019 & 0.366 \\ 0.383 & 0.175 & 0.003 \\ 0.668 & 0.363 & 0.364 \\ & & \\ 0.572 & 0.172 & -0.050 \\ & & \\ 0.293 & 0.123 & -0.018 \\ 0.111 & & \\ \mathbf{3 1 . 8 9} & \mathbf{2 4 . 7 6} & \mathbf{1 3 . 6 1}\end{array}$

\section{Credibility}

Communications

Show unit level management \& business growth

Implement quality standards and operational procedures

Implementation of changes swiftly as \& when needed in operations

Submission of financial statements on time

Meet promises

Demonstrate honesty

Honoring obligations

Show of respect for principles on which system is based

Respect for franchisor's achievements and guidance

\begin{tabular}{cccc}
\hline Operations & Sincerity & Honesty & Acquiescence \\
\hline & & & \\
-0.208 & 0.658 & 0.144 & 0.012 \\
0.414 & 0.664 & -0.128 & 0.115 \\
& & & \\
0.008 & 0.795 & 0.11 & 0.049 \\
& & & \\
0.089 & 0.801 & -0.069 & -0.026 \\
& & & \\
0.23 & 0.416 & -0.09 & 0.71 \\
0.323 & 0.025 & 0.753 & 0.014 \\
-0.169 & 0.101 & 0.822 & -0.106 \\
0.506 & -0.143 & 0.628 & 0.142 \\
& & & \\
0.837 & 0.079 & 0.01 & -0.193 \\
0.36 & 0.172 & -0.009 & -0.811 \\
$\mathbf{2 7 . 7 1}$ & $\mathbf{1 9 . 6 9}$ & $\mathbf{1 3 . 0 7}$ & $\mathbf{1 1 . 0 6}$ \\
\hline
\end{tabular}


Table 3: Factor analysis of relationship domains (cont)

\section{Integrity}

True and correct presentation of financial figures

Payment of royalties on time

On time reporting

Consistency

Show of responsibility

Innovative ideas and input for development Meeting commitments

Respect for system principles

Managerial Financial Respect

Respect for franchisor achievements and guidance

\begin{tabular}{|c|c|c|c|}
\hline & -0.136 & 0.902 & 0.061 \\
\hline me & 0.208 & 0.876 & -0.044 \\
\hline & 0.714 & -0.014 & -0.07 \\
\hline & 0.45 & 0.08 & 0.274 \\
\hline & 0.732 & 0.065 & 0.005 \\
\hline & 0.397 & 0.011 & 0.273 \\
\hline & 0.701 & -0.035 & 0.169 \\
\hline les & 0.149 & -0.068 & 0.786 \\
\hline & 0.042 & 0.067 & 0.78 \\
\hline Variance & 27.86 & 20.27 & 16.56 \\
\hline
\end{tabular}

Recognition Participation

\section{Benevolence}

Recognition of franchisor's efforts

Recognition that franchisor is boss

Participation in innovation

Problem solving approach

Respect for franchisor's achievements and guidance

Variance

$\begin{array}{ll}0.847 & 0.289 \\ & \\ 0.668 & 0.129 \\ 0.226 & 0.795 \\ 0.197 & 0.719\end{array}$

$0.68 \quad 0.048$

33.61

26.07

\begin{tabular}{lll}
\hline Adherence & Proactivity & Mutuality \\
\hline
\end{tabular}

\section{Commitment}

Adherence and implementation of control systems

Show of trust Inputs when required for product / service development

Show of responsibility

Problem solving approach

Consistent performance

Mutual consensus on common issues and objectives

Mutual cooperation to achieve the agreed targets

Adherence to quality standards Implementation of changes advised Clear communications Variance

$\begin{array}{ccc}0.809 & 0.011 & 0.003 \\ 0.802 & -0.080 & -0.265 \\ & & \\ 0.019 & 0.116 & 0.838 \\ -0.043 & 0.775 & 0.201 \\ 0.074 & 0.808 & 0.067 \\ 0.064 & 0.745 & -0.023 \\ & & \\ -0.008 & 0.131 & 0.730 \\ & & \\ -0.211 & 0.224 & 0.418 \\ 0.790 & 0.028 & 0.206 \\ 0.803 & -0.008 & -0.009 \\ 0.148 & 0.767 & 0.216 \\ \mathbf{2 9 . 8 3} & \mathbf{2 1 . 7 7} & \mathbf{1 4 . 9 6}\end{array}$




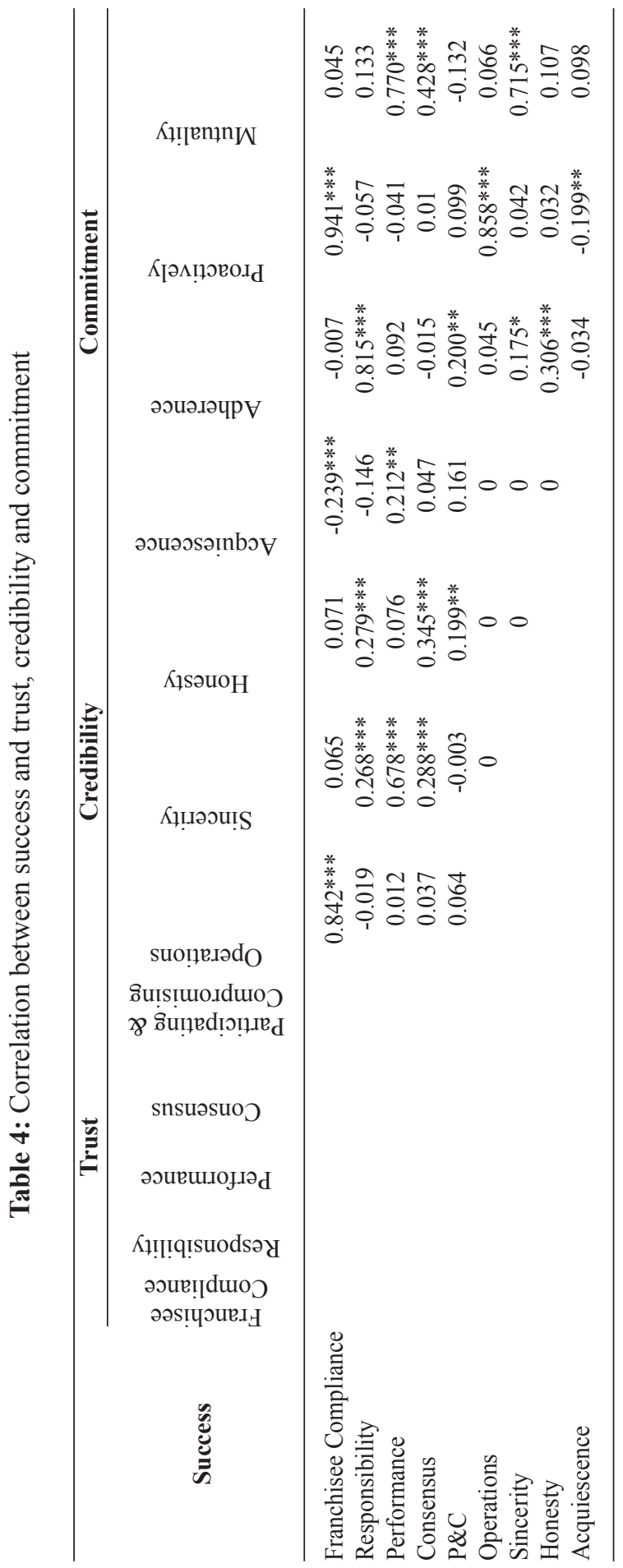




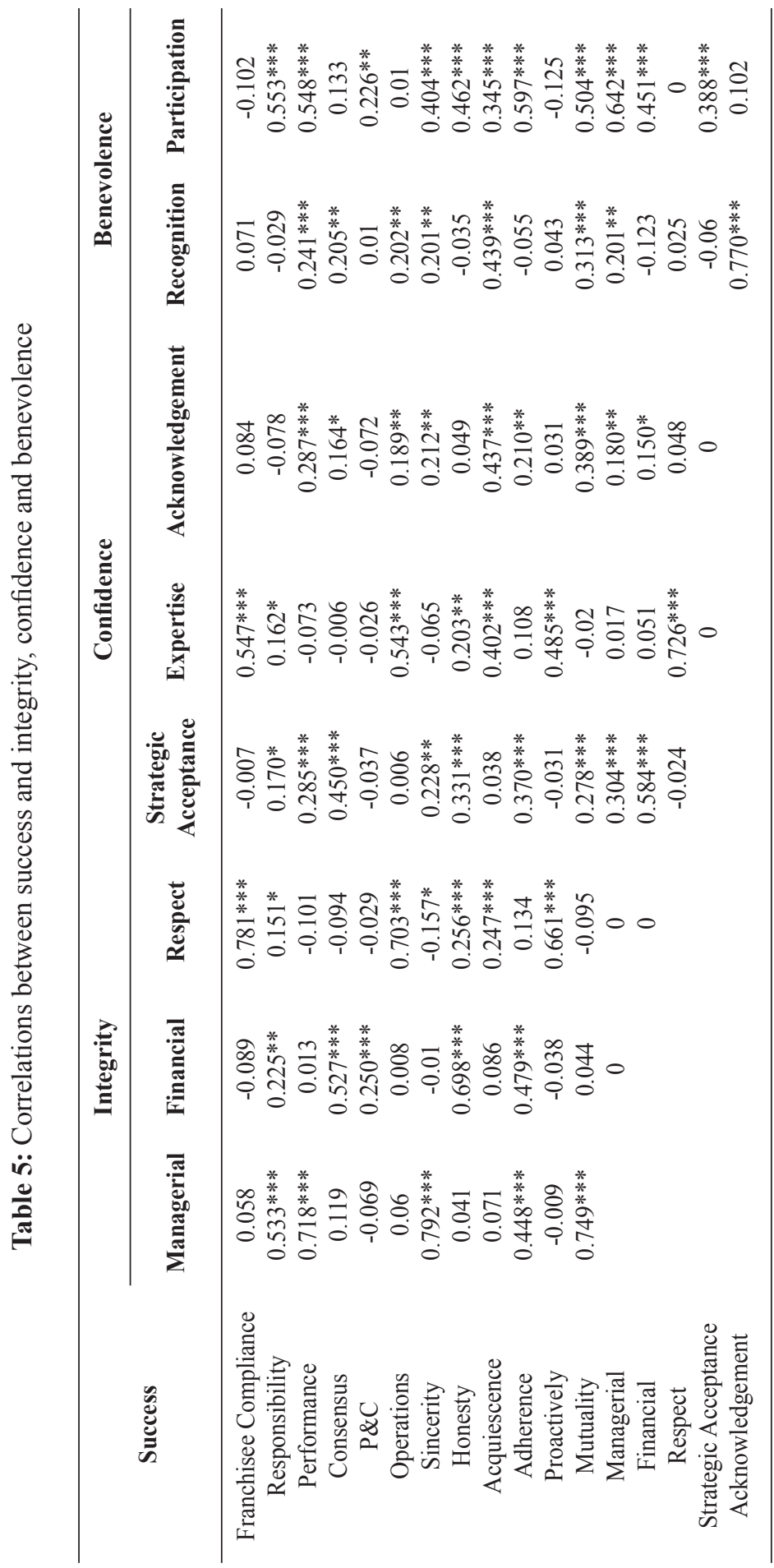


The dimensions of each domain were regressed on success, separately for each domain, on the success score using a stepwise selection procedure and the models obtained is presented in Table 4 and 5. For each domain, with the exception of confidence, only one factor appeared important. For confidence no factors were found to be significant as shown below in table 6 .

Table 6: Regression models of relationship dimensions on success

\begin{tabular}{ccccc}
\hline Domain & Factor & Slope & Standard Error & $\mathbf{R}^{\mathbf{2}} \mathbf{\%}$ \\
\hline Trust & Performance & 4.527 & 1.192 & 10.6 \\
Credibility & Sincerity & 3.032 & 1.230 & 4.7 \\
Commitment & Mutuality & 4.220 & 1.201 & 9.2 \\
Benevolence & Benevolence & 3.160 & 1.227 & 5.2 \\
Integrity & Managerial & 3.043 & 1.280 & 4.8 \\
\hline
\end{tabular}

The above table shows that for the majority of domains there appears a link to explaining the perceived success of the franchise relationship. But the relationship domains are strongly correlated, especially the factors are identified as important. Thus conventional regression is not an appropriate means to construct a model of the relationship to success. Path models were investigated using AMOS 7.0. Many models were fitted and were compared of the basis of their fit criteria and on conceptual appeal. From this the model emerged as optimal is displayed in Figure 1. The slopes of the connecting paths are listed in Table 7 and the contributions to

Figure 1: Path Model

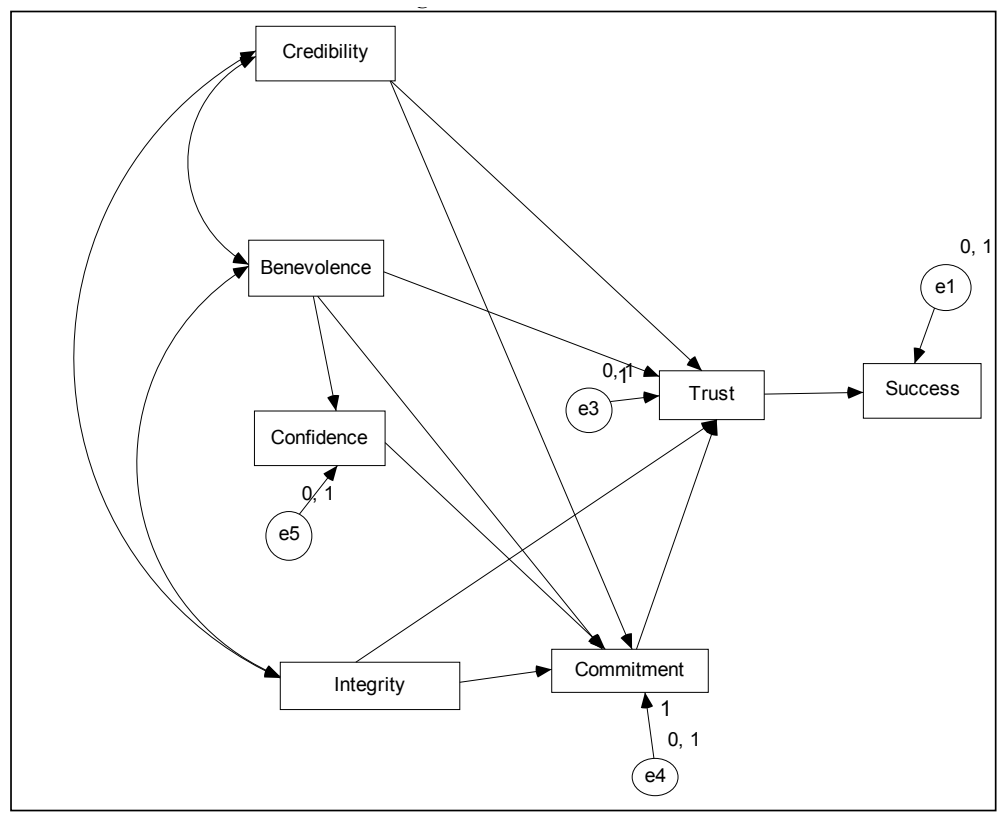


explaining success of the franchise relationship of the various paths are detailed in Table 8. In this formulation credibility, benevolence and integrity are taken as given; these are correlated as indicated by the double headed arrows. These act upon confidence, commitment and trust in franchise relationship. In this formulation the effects on success was found to be via trust.

Table 7: Slopes of connecting line in the path model

\begin{tabular}{cccccc}
\hline Response & Stimulus & Estimate & S.E. & C.R. & P \\
\hline Success & Trust & 4.527 & .899 & 5.037 & $<0.001$ \\
Trust & Integrity & .670 & .118 & 5.664 & $<0.001$ \\
Trust & Benevolence & .376 & .127 & 2.958 & .003 \\
Trust & Commitment & -.432 & .087 & -4.963 & $<0.001$ \\
Confidence & Benevolence & .388 & .091 & 4.284 & $<0.001$ \\
Commitment & Integrity & .420 & .181 & 2.316 & .021 \\
Commitment & Confidence & .167 & .090 & 1.848 & .065 \\
Commitment & Benevolence & .408 & .126 & 3.233 & .001 \\
Commitment & Credibility & -.360 & .152 & -2.368 & .018 \\
\hline
\end{tabular}

Thus the direct effect is verified. Integrity and benevolence relationships act to increase trust and indirectly bolster success. However, commitment seems to have a negative direct effect on trust and this translates to an overall negative effect on success. Trust is indirectly positively affected by confidence via the direct effect of confidence on benevolence. Commitment is enhanced by increasing integrity, confidence and benevolence but adversely influenced by credibility.

Table 8: The effects of relationship on self-reported success

\begin{tabular}{ccccccc}
\hline $\begin{array}{c}\text { Effect on } \\
\text { Success }\end{array}$ & Integrity & Credibility & Confidence & Trust & Commitment & Benevolence \\
\hline Direct & 0.000 & 0.000 & 0.000 & 0.414 & 0.000 & 0.000 \\
Indirect & 0.153 & 0.049 & -0.024 & 0.000 & -0.163 & 0.054 \\
\hline
\end{tabular}

The model appears to be a reasonable fit as indicated by the comparative fit index (Bentler, 1990) of 0.842 (one desires this to be close to one) and the Akaiki Information Criteria of 123.3 which compares well with the null model of 463.2. However, the minimum discrepancy function is 6 well above the desirable level of 2 which indicates lack of fit and room for improvement in the model. 


\section{FURTHER ANALYSIS OF THE RELATIONSHIP DOMAINS}

The factors of each domain of relationship were analyzed in relation to franchise age and franchise size using the categories as detailed in Table 1. As the franchises became older no clear trend in the factors emerge but for large franchises all the key factors associated with success were stronger as can be observed from Figure II.

However, using, 'two way analysis of variance'; on significant difference in self-reported success was found across franchise size or age.

Figure 2: Bar charts of key factors associated with success by age and size

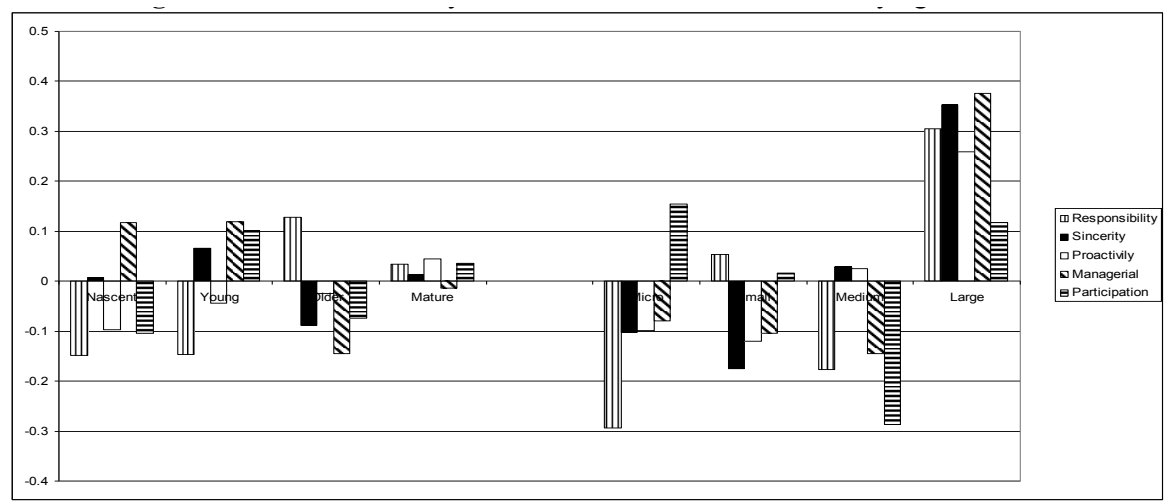

The mean factor scores by different business sectors are displayed in Figure III; this shows at in food and education and training sectors that the relationships tend to be stronger than in the automotive sector where, in line perhaps with popular stereotypes integrity and benevolence factors score low, though the factor from commitment scores high. In the general and specialist retail sectors all the relationships appear weak. However, once again this variation between sectors was not found to affect self-reported success which was found not to vary significantly between the business sectors.

\section{CONCLUSION}

From this study much of the speculation in the literature such as that of Morgan and Hunt (1994) has been verified. Constructs of different facets of relationships in franchising have been constructed. Some of these have been found to contribute directly to the success of the franchise. The stronger these relationships as represented by higher factor scores of their dimensions then the greater is the likelihood of a successful franchise.

Although the direct relation of the relationship to success is weak and not significant for the case of the confidence domain, these relationships reinforce one another and act in the manner of a virtuous circle which enhances the prospect of success. 
Figure 3: Relationship strength by business sector

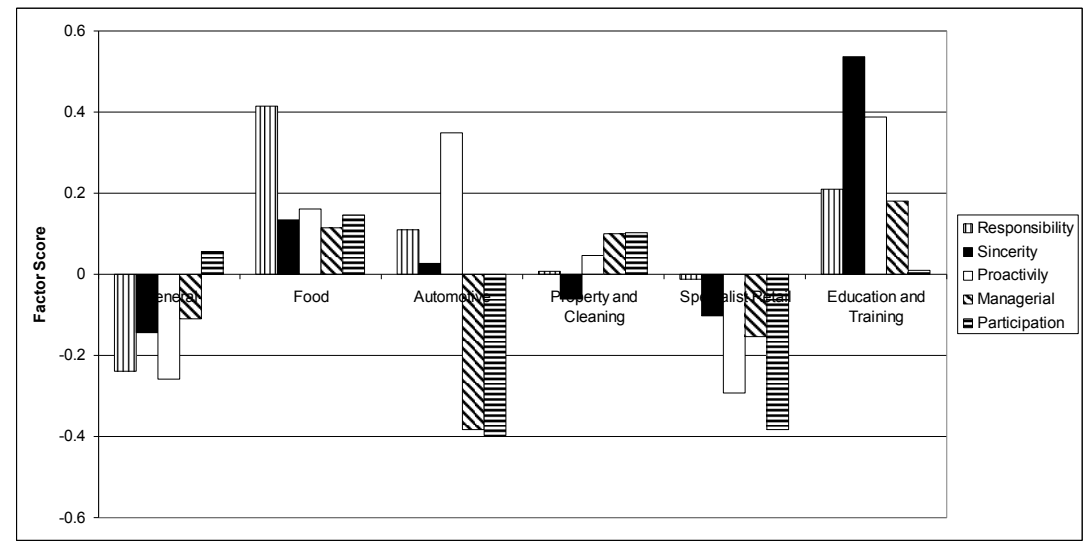

In general these dimensions were found to be stronger in older franchises than newer and smaller franchises but not significantly so.

The business relationships clearly play an important, if somewhat unrevealed part in ensuring the success and ultimately the continuance of the franchise and as such they should be fostered and nurtured.

\section{REFERENCES}

Anderson J. C., Narus, J. A. (1990). A Model of Distributor Firm and Manufacturer Firm Working Partnerships. Journal of Marketing, 54(January), 42-58.

Arthur, W. B. (1996). Increasing Returns and the New World of Business. Harvard Business Review, July-August, 100-109.

Atuahene-Gima, K. (1996). Market Orientation and innovation. Journal of Business Research, 35(2), 93-103.

Barney, J. B. (1991). Firm Resources and Sustained Competitive Advantage. Journal of Management, 17(1), 99-120.

Barney, J. B. (1996). Gaining and Sustaining Competitive Advantage. Reading, Massachusetts: Addison-Wesley Publishing Company.

Baucus, A. W., Baucus, S. M., \& Human, E. S. (1996). Consensus in Franchise Organizations: A Cooperative Arrangement among Entrepreneurs. Journal of Business Venturing, 11(5), 359-378. 
Bentler, P. M. (1990). Comparative fit indexes in structural models. Psychology Bulletin, 107, 238-246.

Bourgeois, L. J. (1980). Performance and Consensus. Strategic Management Journal, 1(3), $227-248$

Child, J., \& Faulkner, D. (1998). Strategies for Cooperation. Managing Alliances, Networks and Joint Ventures. Oxford: Oxford University Press

Coletti, A. L., Sedatole, K. L., \& Towry, K. L. (2005). The Effect of Control Systems on Trust and Cooperation in Collaborative Environments. The Accounting Review, 80(2), $477-500$

Contractor, F. J., \& Lorange, P. (1988). Cooperative Strategies in International Business. Lexington, MA: Lexington Books.

Coote, L. V., Forrest, E. J., \& Tam, T. W. (2003). An investigation into Commitment in Non Western industrial Marketing Relationships. Industrial Marketing Management, 32(7), 595-604.

Costa, A. C. (2003). Work Team Trust and Effectiveness. Personnel Review, 32(5), 605-622.

Cunningham, M. T., \& Homse, E. (1986). Controlling The Marketing-Purchasing Interface: Resource Deployment and Organizational structure. Industrial Marketing and Purchasing, 1(2) 8-25.

Dant, R. P., \& Nasr, N. I. (1998). Control Techniques and Upward Flow of information in Franchising in Distant Markets: Conceptualisation and Preliminary Evidence. Journal of Business Venturing, 13(1), 9-28.

De Ruyter, K. L., Moorman, C., \& Lemmink, J. (2001). Antecedents of Commitment and Trust in Customer-Supplier Relationships in High Technology Markets. Industrial Marketing Management, 30(3), 271-286.

Dess, G., \& Davis, P. (1984). Porter's 1980 Generic Strategies as Determinants of Strategic Group Membership and Organisational Performance. Academy of Management Journal, $27(3)$ 467-488.

Foster, J., Barkus, E., \& Yavorsky, C. (2006). Understanding and Using Advanced Statistics, Sage Publications.

Frigo, L. M. (2003). Strategy, Value Creation, and the CFO. Strategic Finance, 84(7) 9-11.

Ganesan, S. (1994). Determinants of Long-Term Orientation in Buyer-Seller Relationships. Journal of Marketing, 58(2) 1-20.

Geyskens, I., Benedict, J. S., \& Kumar, N. (1999). A Meta-Analysis of Satisfaction in Marketing Channel Relationships. Journal of Marketing Research, 36(2), 223-238. 
Gundlach, G. T., Achrol, M., Ravi, S., \& Mentzer, J. T. (1995). Structure of Commitment in Exchange. Journal of Marketing, Chicago, 59(1) 55-78.

Hadjikhani, A., \& Thilenius, P. (2005). The Impact of Horizontal and Vertical Connections on Relationship's Commitment and Trust. Journal of Business and industrial Marketing, $20(3)$ 136-147.

Hakansson, H., \& Snehota, I. (1995). Developing Relationships in Business Networks. London: Routledge.

Holm, B. D., Eriksson, K., \& Johanson, J. (1999). Creating Value through Mutual Commitment to Business Network Relationships. Strategic Management Journal, 20(5) 467-479.

Huxham, C., \& Macdonald, D. (1992). Introducing Collaborative Advantage: Achieving Inter-Organisational Effectiveness through Meta-Strategy. Management Decision, 30(3) $50-56$.

Inkpen, A. C., \& Birkenshaw, J, (1994). International Joint Ventures and Performance: An Inter-organizational Perspective. International Business Review, 3(3) 201-217.

Kidder, L. H., \& Judd, C. M. (1986). Research Methods in Social Relations. New York: Holt, Rinehart and Winston.

Lawler, E. J., \& Yoon, J. (1996). Commitment in Exchange Relations: Test of A Theory of Relational Cohesion. American Sociological Review, 61(1), 89-108.

Mayer, R. C., \& Davis, J. H., \& Schoorman, F. D. (1995). An integrative Model of Organizational Trust. Academy of Management Review, 20(3), 709-34

Miyamoto, T., \& Rexha, N. (2004). Determinants of Three Facets of Customer Trust: A Marketing Model of Japanese Buyer-Supplier Relationship. Journal of Business Research, 57(3), 312-319.

Moorman, C., D. R., Zaltman, G. (1993). Factors Affecting Trust in Market Research Relationships. Journal of Marketing, 54(1), 81-101.

Morgan, R. M., \& Hunt, S. D. (1994). The Commitment-Trust Theory of Relationship Marketing. Journal of Marketing, 58(3), 20-39.

Ndubisi, L., \& Wah, G. (2005). Factorial and Discriminant Analyses of the Underpinnings of Relationship Marketing and Customer Satisfaction. International Journal of Bank Marketing, 23(7), 542-557

Nicholson, C. Y., Compeau, L. D., \& Sethi, R. (2001). The Role of Interpersonal Liking in Building Trust in Long-Term Channel Relationships. Journal of the Academy of Marketing Science, 29 (1), 3-15. 
Perry, C., Cavaye, A., \& Coote, L. (2002). Technical and Social Bonds within Business To Business Relationships. The Journal of Business and International Marketing, 17(1) $75-88$.

Powell, W. W. (1987). Hybrid Organizational Arrangements: New Form or Transitional Development? California Management Review, 30(1) 67-87.

Powell, W. W. (1990). Neither Market nor Hierarchy: Networks Form Organisations. In B.M. Staw, \& L. L. Cummings (Eds.), Research in Organisational Behaviour (pp. 295-336). Greenwich: JAI-Press.

Ring, P. S., \& Van-De-Ven, A. H. (1994). Development Process of Cooperative InterOrganisational Relationships. Academy of Management Review, 19(1) 90-118.

Sako, M. (2000). Modules in Design, Production and Use: Implications for the Global Automotive industry. Paper prepared for the International Motor Vehicle Program, Cambridge Mass. USA.

Salthouse, T. A., Berish, D. E., \& Siedlecki, K. L. (2004). Construct Validity and Age Sensitivity of Prospective Memory. Psycho-Nomic Society Publications, 32(7), 11331148

Sarkar, M. S., Cavusgil, T., \& Evirgen, C. (1997). A Commitment-Trust Mediated Framework of International Collaborative Venture Performance. In P. Beamish \& J. P. Killing (Eds.), Cooperative Strategies: North American Perspectives (255-285). San Francisco: New Lexington Press.

Shane, S. A. (1996). Hybrid Organizational Arrangements and Implications for Firm Growth and Survival: A Study of New Franchisors. Academy of Management Journal, 39(1), 216-235.

Shane, S. A., \& Spell, C. (2002). What Successful Franchisors Have In Common? Retrieved June 2, 2005, from http://www.franchise.co.nz/article/view/69

Swenson, M. J., Rinne, H., \& Geurts, M. (1990). Why Franchise Channels Are Different, Franchising: Evolution in The Midst of Change. Paper presented at the Annual Conference of the Society of Franchising, Scottsdale, AZ, and February 2-24.

Tellefsen, T. (2002). Commitment in Business-To-Business Relationships. Industrial Marketing Management, 31(8), 645-652.

Ulaga, W., \& Eggert, A. (2006). Relationship Value and Relationship Quality, Broadening the Nomological Network of Business-To-Business Relationships. European Journal of Marketing, 40(3/4) 311-327. 